\title{
Developing Community-Level Policy and Practice to Reduce Traffic-Related Air Pollution Exposure
}

\author{
Doug Brugge, Allison P. Patton, Alex Bob, Ellin Reisner, Lydia Lowe, Oliver-John M. Bright, \\ John L. Durant, Jim Newman, and Wig Zamore
}

\begin{abstract}
The literature consistently shows associations of adverse cardiovascular and pulmonary outcomes with residential proximity to highways and major roadways. Air monitoring shows that trafficrelated air pollutants (TRAP) are elevated within 200-400 meters of these roads. Community-level tactics for reducing exposure include the following: 1) high-efficiency particulate arrestance (HEPA) filtration; 2) appropriate air-intake locations; 3) sound proofing, insulation; 4) land-use buffers; 5) vegetation or wall barriers; 6) street-side trees, hedges and vegetation; 7) decking over highways; 8) urban design including placement of buildings; 9) garden and park locations; and 10) active-travel locations, including bicycling and walking paths. A multidisciplinary design charrette was held to test the feasibility of incorporating these tactics into near-highway housing and school developments that were in the planning stages. The resulting designs successfully utilized many of the protective tactics and also led to engagement with the designers and developers of the sites. There is a need to increase awareness of TRAP in terms of building design and urban planning.
\end{abstract}

\section{HIGHWAY PROXIMITY AND HEALTH}

$\mathbf{C}$ ONCENTRATIONS OF TRAFFiC-RELATED AIR POLLUTANTS (TRAP) are frequently elevated next to highways and major roadways. The mixture of gasses and

Dr. Brugge is professor in the Department of Public Health and Community Medicine at Tufts University School of Medicine in Boston, Massachusetts. Dr. Patton is a post-doctoral fellow in the Environmental and Occupational Health Sciences Institute at Rutgers University in Piscataway, New Jersey. Mr. Bob is at the Office of Strategic Planning and Community Development, City of Somerville, in Somerville, Massachusetts. Dr. Reisner is the president of the Somerville Transportation Equity Partnership in Somerville, Massachusetts. Ms. Lowe is the executive director of the Chinese Progressive Association in Boston, Massachusetts. Mr. Bright is in the Department of Public Health and Community Medicine at Tufts University School of Medicine in Boston, Massachusetts. Dr. Durant is an associate professor in the Department of Civil and Environmental Engineering at Tufts University in Boston, Massachusetts. Mr. Newman is the founder and principal at Linnean Solutions in Cambridge, Massachusetts. Mr. Zagmore is at the Somerville Transportation Equity Partnership in Somerville, Massachusetts.

(c) The Author(s) 2015; Published by Mary Ann Liebert, Inc. This Open Access article is distributed under the terms of the Creative Commons Attribution Noncommercial License (http:// creativecommons.org/licenses/by-nc/4.0/) which permits any noncommercial use, distribution, and reproduction in any medium, provided the original author(s) and the source are credited. particles in fresh motor vehicle exhaust emissions are distinct from other air pollutants that are spread more evenly over large metropolitan areas. Key pollutants in TRAP include ultrafine particles (UFP, particles $<0.1$ microns in diameter), black carbon, $\mathrm{PM}_{10}$ (particles $<10$ microns in diameter), nitrogen oxides (including nitrogen dioxide and nitrogen oxide, NO), carbon monoxide, and volatile organic compounds. ${ }^{1,2,3}$ Thus, people who live or spend time in locations adjacent to busy roadways are more highly exposed to these pollutants.

\footnotetext{
${ }^{1}$ Alex A. Karner, Douglas S. Eisinger, and Deb A. Niemeier, "Near-Roadway Air Quality: Synthesizing the Findings from Real-World Data," Environmental Science and Technology 44 (July 15, 2010): 5334-44, doi:10.1021/es100008x.

${ }^{2}$ Allison P. Patton et al., "Spatial and Temporal Differences in Traffic-Related Air Pollution in Three Urban Neighborhoods near an Interstate Highway," Atmospheric Environment 99 (Dec. 2014): 309-21, doi:10.1016/j.atmosenv.2014. 09.072.

${ }^{3}$ Luz T. Padró-Martínez et al., "Mobile Monitoring of Particle Number Concentration and Other Traffic-Related Air Pollutants in a near-Highway Neighborhood over the Course of a Year," Atmospheric Environment 61 (Dec. 2012): 25364, doi:10.1016/j.atmosenv.2012.06.088.
} 
Many studies have looked at where people live relative to major roadways and investigated whether closer proximity puts them at greater risk of adverse health outcomes. These "proximity studies" have consistently found that living closer to heavy traffic is associated with childhood asthma and reduced lung function, ${ }^{4,5}$ cardiovascular health and mortality, ${ }^{6,7}$ biomarkers of cardiovascular health, ${ }^{8}$ and development of autism. ${ }^{9,10}$

We have been conducting community-based participatory research projects under the umbrella of the Community Assessment of Freeway Exposure and Health (CAFEH; < http://sites.tufts.edu/cafeh/>) study to look at the possible role of UFP on the health of residents living near heavy traffic. Other research suggests that UFP might be a causal agent of near highway health effects. Animal studies have reported that UFP can penetrate deep into the lungs and translocate into the blood. UFP promote inflammation, oxidative stress, and atherosclerosis in animals. ${ }^{11,12,13}$ Both controlled human exposure studies and studies of short term association

${ }^{4}$ Rob McConnell et al. "Childhood Incident Asthma and Traffic-Related Air Pollution at Home and School," Environmental Health Perspectives 118 (July 2010): 1021-26, doi:10.1289/ehp.0901232.

${ }^{5}$ W. James Gauderman et al., "Childhood Asthma and Exposure to Traffic and Nitrogen Dioxide," Epidemiology 16 (Nov. 2005): 737-43.

${ }^{6}$ Michael Jerrett et al., "A Cohort Study of Traffic-Related Air Pollution and Mortality in Toronto, Ontario, Canada," Environmental Health Perspectives 117 (May 2009): 772-77, doi:10.1289/ehp.11533.

${ }^{7}$ Wen Qi Gan et al., "Changes in Residential Proximity to Road Traffic and the Risk of Death from Coronary Heart Disease," Epidemiology 21 (Sept. 2010): 642-49, doi:10.1097/EDE.0b013e3181e89f19.

${ }^{8}$ Doug Brugge et al., "Highway Proximity Associated with Cardiovascular Disease Risk: The Influence of IndividualLevel Confounders and Exposure Misclassification," Environmental Health 12 (Oct. 3, 2013): 84, doi:10.1186/ 1476-069X-12-84.

${ }^{9}$ Heather E. Volk et al., "Traffic-Related Air Pollution, Particulate Matter, and Autism," JAMA Psychiatry 70 (Jan. 2013): 71-77, doi:10.1001/jamapsychiatry.2013.266.

${ }^{10}$ Andrea L. Roberts et al., "Perinatal Air Pollutant Exposures and Autism Spectrum Disorder in the Children of Nurses' Health Study II Participants," Environmental Health Perspectives 121 (Aug. 2013): 978-84, doi:10.1289/ehp. 1206187.

${ }^{11}$ Jesus A. Araujo et al., "Ambient Particulate Pollutants in the Ultrafine Range Promote Early Atherosclerosis and Systemic Oxidative Stress," Circulation Research 102 (Mar. 14, 2008): 589-96, doi:10.1161/CIRCRESAHA.107. 164970.

${ }^{12}$ Jesus A. Araujo and Andre E. Nel, "Particulate Matter and Atherosclerosis: Role of Particle Size, Composition and Oxidative Stress," Particle and Fibre Toxicology 6 (Sept. 18, 2009): 24, doi:10.1186/1743-8977-6-24.

${ }^{13}$ Marianne Geiser et al., "Ultrafine Particles Cross Cellular Membranes by Nonphagocytic Mechanisms in Lungs and in Cultured Cells," Environmental Health Perspectives 113 (Nov. 2005): 1555-60. with UFP add evidence that UFP affect inflammation and coagulation. $^{14,15,16,17,18,19}$

In CAFEH, we monitored UFP in both near highway ( $<400$ meters from highways) and urban background $(>1$ kilometer from highways) neighborhoods ${ }^{20}$ and collected blood biomarker samples and lifestyle information from participants living in these locations. Resulting data were used to build land use regression models of UFP for the study areas. ${ }^{21}$ These models predict hourly UFP levels at participants' residences for every hour for a year. Subsequently, we modified participant exposure by their time activity patterns and use of air conditioning. The resulting individualized exposures were used to test associations with blood biomarkers of inflammation and coagulation, which are predictors of cardiovascular disease risk. We have not published our main findings for association of UFP with the biomarkers and cannot report them here.

\section{ENVIRONMENTAL JUSTICE}

TRAP is an environmental justice issue because lowincome and minority populations are disproportionately concentrated near high traffic volume roadways. A U.S. -wide study that linked National Health and Nutrition Examination Survey data to the National Highway Planning Network found that non-Hispanic blacks, Mexican Americans, and people living just above or below the poverty line were more likely to have higher

\footnotetext{
${ }^{14}$ Robert B. Devlin et al., "Controlled Exposure of Humans with Metabolic Syndrome to Concentrated Ultrafine Ambient Particulate Matter Causes Cardiovascular Effects," Toxicological Sciences: An Official Journal of the Society of Toxicology 140 (July 2014): 61-72, doi:10.1093/toxsci/kfu063.

${ }^{15}$ A. Nemmar et al., "Passage of Inhaled Particles into the Blood Circulation in Humans," Circulation 105 (Jan. 29, 2002): 411-14.
}

${ }^{16}$ James M. Samet et al., "Concentrated Ambient Ultrafine Particle Exposure Induces Cardiac Changes in Young Healthy Volunteers," American Journal of Respiratory and Critical Care Medicine 179 (June 1, 2009): 1034-42, doi:10.1164/rccm.2008071043 OC.

${ }^{17}$ Ralph J. Delfino et al., "Circulating Biomarkers of Inflammation, Antioxidant Activity, and Platelet Activation Are Associated with Primary Combustion Aerosols in Subjects with Coronary Artery Disease," Environmental Health Perspectives 116 (July 2008): 898-906, doi:10.1289/ehp.11189.

${ }^{18}$ Ralph J. Delfino et al., "Association of Biomarkers of Systemic Inflammation with Organic Components and Source Tracers in Quasi-Ultrafine Particles," Environmental Health Perspectives 118 (June 2010): 756-62, doi:10.1289/ehp.0901407.

${ }^{19}$ Sabine Hertel et al., "Influence of Short-Term Exposure to Ultrafine and Fine Particles on Systemic Inflammation," European Journal of Epidemiology 25 (Aug. 2010): 581-92, doi:10.1007/ s10654-010-9477-X.

${ }^{20}$ Christina H Fuller et al., "A Community Participatory Study of Cardiovascular Health and Exposure to near-Highway Air Pollution: Study Design and Methods," Reviews on Environmental Health 28 (2013): 21-35, doi:10.1515/reveh-20120029.

${ }^{21}$ Allison P. Patton et al., "An Hourly Regression Model for Ultrafine Particles in a Near-Highway Urban Area," Environmental Science and Technology 48 (Mar. 18, 2014): 3272-80, doi:10.1021/es404838k. 
TRAP exposure. ${ }^{22}$ Two other studies recently conducted similar investigations of traffic exposure in the U.S. Both studies had similar findings. The first used census track level data and found that residential location of nonHispanic blacks and Hispanics had positive Spearman correlation coefficients with road density. They also found a similar association for poverty. ${ }^{23}$ The second study analyzed national data at a finer grain, using census blocks. This study also found that being non-Hispanic black, Hispanic, and low-income were associated with higher traffic volume and density. They also found that greater racial and income disparity were associated with increased traffic density. ${ }^{24}$

\section{PRINCIPLES FOR REDUCING OR AVOIDING UFP EXPOSURE}

Development of protective tactics for near-highway locations requires knowledge of atmospheric processes and TRAP emission rates. It is important to note that UFP concentrations change rapidly in time and space, which makes understanding exposure complex. However, because highway traffic patterns and UFP emission rates are predictable, we can build fairly reliable models to predict UFP concentrations at different locations and times. ${ }^{25,26}$ General principles for reducing or avoiding exposure should consider: 1) wind direction; 2) wind speed; 3) distance from busy roadways; 4) time of day; and 5) time of year. For example, based on the CAFEH study we found that the highest UFP concentrations occurred in Somerville within 0-50 meters of Interstate 93 (I-93) with distance-decay gradients varying depending on traffic and meteorology. ${ }^{27}$

The annual median particle number concentration (PNC, a proxy for UFP) 0-50 meters from I-93 was twofold higher compared to the background area ( $>1$ kilo-

\footnotetext{
${ }^{22}$ Jennifer Parker et al., Linkage of the 1999-2008 National Health and Nutrition Examination Surveys to Traffic Indicators From the National Highway Planning Network, National Health Statistics Report (U.S. Department of Health and Human Services, Apr. 2, 2012).

${ }^{23}$ Nancy Tian, Jianping Xue, and Timothy M. Barzyk, "Evaluating Socioeconomic and Racial Differences in TrafficRelated Metrics in the United States Using a GIS Approach," Journal of Exposure Science and Environmental Epidemiology 23 (Mar. 2013): 215-22, doi:10.1038/jes.2012.83.

${ }^{24}$ Gregory M. Rowangould, "A Census of the US near-Roadway Population: Public Health and Environmental Justice Considerations," Transportation Research Part D Transport and Environment 25 (2013): 59-67, doi:10.1016/j.trd.2013.08.003.

${ }^{25}$ Allison P. Patton et al., "An Hourly Regression Model for Ultrafine Particles in a Near-Highway Urban Area," Environmental Science and Technology 48 (Mar. 18, 2014): 3272-80, doi:10.1021/es404838k.

${ }^{26}$ Leonard M. Zwack et al., "Modeling Spatial Patterns of Traffic-Related Air Pollutants in Complex Urban Terrain," Environmental Health Perspectives 119 (June 2011): 852-59, doi:10.1289/ehp.1002519.

${ }^{27}$ Luz T. Padró-Martínez et al., "Mobile Monitoring of Particle Number Concentration and Other Traffic-Related Air Pollutants in a near-Highway Neighborhood over the Course of a Year," Atmospheric Environment 61 (Dec. 2012): 253-64, doi:10.1016/j.atmosenv.2012.06.088.
}

meter from I-93). PNC was generally highest in winter and lowest in summer and fall, higher on weekdays compared to weekends, and higher during morning rush hour compared to later in the day. For winds out of the southwest and northwest, PN concentrations were elevated on the northeast side of I-93 relative to the southwest side, and when winds were out of the northeast the opposite occurred, indicating that I-93 is the dominant source of PNC to neighborhoods immediately downwind of the highway. PNC was also greatly impacted by wind speed: median PN concentrations were highest for calm winds $(<0.3$ meters per second) and lowest for wind speeds $>1.6$ meters per second.

\section{TACTICS FOR REDUCING COMMUNITY EXPOSURE}

Evidence for efficacy of different tactics to reduce near-highway communities' TRAP exposure was reviewed. These tactics derive from empirical research and are intended for consideration in building and community design. They comprise methods to reduce TRAP generation, prevent pollution from reaching locations people frequent, and move people away from pollution. We searched for studies specifically measuring air pollutant concentration differences as a result of each tactic in PubMed and in the urban planning and environmental science literature. Although many papers claim that these tactics reduce TRAP exposure and improve health, there were limited measurements demonstrating these effects. Therefore, effectiveness of the different tactics based on the literature was classified as good ( $>40 \%$ potential reduction), moderate $(<40 \%$ potential reduction), or inconclusive (insufficient evidence) for both on-site and off-site tactics (Table 1).

Land use buffers can often be used to separate sensitive land uses (e.g., residences, schools) from traffic and other sources of air pollution. TRAP exposure zones with concentrations $40 \%$ to $90 \%$ higher than concentrations in urban backgrounds extend about 50 meters to 1,500 meters from highways and major roads, with most pollutants decreasing to background levels within 300

Table 1. Summary of Expected Effectiveness of DifFERENT TACTICS

\begin{tabular}{|c|c|c|c|}
\hline \multirow[b]{2}{*}{ Location } & \multicolumn{3}{|c|}{ Effectiveness } \\
\hline & Good & Moderate & Inconclusive \\
\hline On-Site & $\begin{array}{l}\text { - Filtration } \\
\text { - Air intake } \\
\text { location } \\
\text { - Sound } \\
\text { proofing }\end{array}$ & $\begin{array}{l}\text { - Healthy placement } \\
\text { of buildings and } \\
\text { parking } \\
\text { structures } \\
\text { - Trees and Plantings }\end{array}$ & $\begin{array}{l}\text { - Healthy } \\
\text { vegetables }\end{array}$ \\
\hline Off-Site & $\begin{array}{l}\text { - Park } \\
\text { locations } \\
\text { - Land use } \\
\text { buffers }\end{array}$ & $\begin{array}{l}\text { - Built or vegetative } \\
\text { barriers } \\
\text { - Active travel } \\
\text { locations } \\
\text { - Decking over } \\
\text { highways }\end{array}$ & \\
\hline
\end{tabular}


meters to 500 meters and at shorter distances upwind than downwind. ${ }^{28,29,30,31,32}$

Siting parks requires consideration of competing factors. Although poor siting (e.g., in TRAP exposure zones) can expose children to air pollution, parks also provide benefits and services that might outweigh pollutant health risks, especially for communities without alternative park space. ${ }^{33,34,35}$

Reducing pollution entry into buildings is the most effective on-site method to reduce TRAP exposure indoors. Multiple guidelines support moving air inlets to locations with cleaner air. ${ }^{36,37,38}$ Research suggests placing air intakes on rooftops or on sides of buildings that do not face roads can decrease pollutant concentrations indoors. ${ }^{39,40}$ Infiltration of TRAP can also be re-

${ }^{28}$ HEI panel on the health effects of traffic-related air pollution, Traffic-Related Air Pollution: A Critical Review of the Literature on Emissions, Exposure, and Health Effects, HEI Special Report 17 (Boston, MA: Health Effects Institute, 2010), $<$ http://cdm16064.contentdm.oclc.org/cdm/ref/collection/ p266901coll4/id/2584>.

${ }^{29}$ Alex A. Karner, Douglas S. Eisinger, and Deb A. Niemeier, "Near-Roadway Air Quality: Synthesizing the Findings from Real-World Data," Environmental Science and Technology 44 (July 15, 2010): 5334-44, doi:10.1021/es100008x.

${ }^{30}$ Allison P. Patton et al., "Spatial and Temporal Differences in Traffic-Related Air Pollution in Three Urban Neighborhoods near an Interstate Highway," Atmospheric Environment 99 (Dec. 2014): 309-21, doi:10.1016/j.atmosenv.2014.09.072.

${ }^{31}$ Luz T. Padró-Martínez et al., "Mobile Monitoring of Particle Number Concentration and Other Traffic-Related Air Pollutants in a near-Highway Neighborhood over the Course of a Year," Atmospheric Environment 61 (Dec. 2012): 253-64, doi:10.1016/j.atmosenv.2012.06.088.

${ }^{32}$ J. L. Durant et al., "Short-Term Variation in near-Highway Air Pollutant Gradients on a Winter Morning," Atmospheric Chemistry and Physics (Print) 10 (2010): 5599-5626.

${ }^{33}$ Anna Chiesura, "The Role of Urban Parks for the Sustainable City," Landscape and Urban Planning 68 (May 15, 2004): 129-38, doi:10.1016/j.landurbplan.2003.08.003.

${ }^{34}$ Zhou Yuan, Shi Tiemao, and Gao Chang, "Multi-Objective Optimal Location Planning of Urban Parks," in 2011 International Conference on Electronics, Communications and Control (ICECC), 2011, 918-21, doi:10.1109/ICECC.2011.6066364.

${ }^{5}$ M. N. Neema and A. Ohgai, "Multi-Objective Location Modeling of Urban Parks and Open Spaces: Continuous Optimization," Computers, Environment and Urban Systems 34 (Aug. 2010): 359-76, doi:10.1016/j.compenvurbsys.2010.03.001.

${ }^{36}$ Standards 62.1 and 62.2: The Standards for Ventilation and Indoor Air Quality (ASHRAE, 2013), 1, < https://www.ashrae.org/ resources-publications/bookstore/standards-62-1-62-2 > (last accessed on Dec. 15, 2014).

${ }^{37}$ American Lung Association of the Upper Midwest, "Health House," n.d., < http://www.healthhouse.org/ > (last accessed on Dec. 15, 2014).

38، Air Quality Standards and Area Designations," California Environmental Protection Agency Air Resources Board, Apr. 17, 2014, < http://www.arb.ca.gov/homepage.htm > (last accessed on Dec. 15, 2014).

${ }^{39}$ N. E Green, D. W Etheridge, and S. B Riffat, "Location of Air Intakes to Avoid Contamination of Indoor Air: A Wind Tunnel Investigation," Building and Environment 36 (Jan. 1, 2001): 1-14, doi:10.1016/S0360-1323(99)00056-6.

${ }^{40}$ Tsang-Jung Chang, Hong-Ming Kao, and Yi-Fang Hsieh, "Numerical Study of the Effect of Ventilation Pattern on Coarse, Fine, and Very Fine Particulate Matter Removal in Partitioned Indoor Environment," Journal of the Air and Waste Management Association (1995) 57 (Feb. 2007): 179-89. duced by tightening buildings, frequently achieved using soundproofing or energy efficiency measures. ${ }^{41,42,43,44,45}$

Filtration is an effective method for improving indoor air quality. In the U.S., filters are rated based on the minimum efficiency reporting value (MERV, higher is more efficient) for particles in the $0.3-1 \mu \mathrm{m}, 1-3 \mu \mathrm{m}$, and $3-10 \mu \mathrm{m}$ size ranges. ${ }^{46,47,48}$ Although minimum efficiencies are not reported for UFP, pilot studies have shown that at least some high-MERV filters can remove UFP. ${ }^{49,50}$ Challenges with filtration include improper filter replacement and long term maintenance. ${ }^{51}$

Moderate effectiveness can also be achieved through urban design. For example, avoiding wind flow through open areas below raised highways or orienting street canyons so that wind flows through them instead of stagnating could reduce pollutant concentrations by one third to one half. 52,53,54,55 In addition, garages and street parking could be distributed so as to decrease driving or low emissions zones

${ }^{41}$ Birgitta Berglund, Thomas Lindvall, and Dietrich $\mathrm{H}$. Schwela, Guidelines for Community Noise (Geneva: World Health Organization, 1999).

${ }^{42}$ U.S. Department of Transportation Federal Highway Administration, Highway Traffic Noise: Analysis and Abatement Guidance (2011).

${ }^{43}$ Berglund, Lindvall, and Schwela, Guidelines for Coтmunity Noise.

${ }^{44}$ Lars Jarup et al., "Hypertension and Exposure to Noise Near Airports: The HYENA Study," Environmental Health Perspectives 116 (Mar. 2008): 329-33, doi:10.1289/ehp.10775.

${ }^{45}$ Thomas Münzel et al., "Cardiovascular Effects of Environmental Noise Exposure," European Heart Journal (Mar. 8, 2014), ehu030, doi:10.1093/eurheartj/ehu030.

${ }^{46}$ United States Environmental Protection Agency, Residential Air Cleaners: A Summary of Available Information (2009).

${ }^{47}$ B. Stephens and J. A. Siegel, "Ultrafine Particle Removal by Residential Heating, Ventilating, and Air-Conditioning Filters," Indoor Air 23 (Dec. 1, 2013): 488-97, doi:10.1111/ ina.12045.

${ }^{48}$ Bin Zhou and Jinming Shen, "Comparison of General Ventilation Air Filter Test Standards between America and Europe" (The 6th International Conference on Indoor Air Quality, Ventilation and Energy Conservation in Buildings IAQVEC, Sendai, Japan, 2007).

${ }^{49}$ A. Polidori et al., "Pilot Study of High-Performance Air Filtration for Classroom Applications," Indoor Air 23 (June 2013): 185-95, doi:10.1111/ina.12013.

${ }^{50}$ Stephens and Siegel, "Ultrafine Particle Removal by Residential Heating, Ventilating, and Air-Conditioning Filters."

${ }^{51}$ S. Batterman et al., "Particulate Matter Concentrations in Residences: An Intervention Study Evaluating Stand-Alone Filters and Air Conditioners," Indoor Air 22 (June 2012): 23552, doi:10.1111/j.1600-0668.2011.00761.x.

${ }^{52}$ J. H. Amorim et al., "CFD Modelling of the Aerodynamic Effect of Trees on Urban Air Pollution Dispersion," Science of The Total Environment 461-462 (Sept. 1, 2013): 541-51, doi:10.1016/j.scitotenv.2013.05.031.

${ }^{53}$ Peter E. J. Vos et al., "Improving Local Air Quality in Cities: To Tree or Not to Tree?," Environmental Pollution 183 (Dec. 2013): 113-22, doi:10.1016/j.envpol.2012.10.021.

${ }^{54}$ Amorim et al., "CFD Modelling of the Aerodynamic Effect of Trees on Urban Air Pollution Dispersion."

${ }^{55}$ Zheming Tong et al., "Modeling Spatial Variations of Black Carbon Particles in an Urban Highway-Buildings Environment," Environmental Science and Technology 46 (Jan. 3, 2012): 312-19, doi:10.1021/es201938v. 
could substitute some of the vehicle fleet with electric vehicles. $^{56,57}$

Urban vegetation including green roofs or walls can also decrease air pollution slightly, particularly in highly polluted cities (e.g., Mexico City), through deposition on leaf surfaces and reduced need for air conditioning due to the cooling effect provided by the soil layer and building shade. ${ }^{58,59,60,61,62}$ Vegetation along the side of a busy road can reduce air pollution behind the vegetative barrier by less than $40 \%$, although results vary greatly by wind direction and study. ${ }^{63,64}$ When planning urban vegetation, it is important to note that vegetation in street canyons can increase pollutant concentrations by as much as $33 \%$ due to decreasing wind flow and ventilation. ${ }^{65,66,67,68,69}$ Off-site,

${ }^{56}$ Paul G. Höglund, "Parking, Energy Consumption and Air Pollution," Science of the Total Environment 334-335 (Dec. 1, 2004): 39-45, doi:10.1016/j.scitotenv.2004.04.028.

${ }^{57}$ J. A. Acero et al., "Impact of Local Urban Design and Traffic Restrictions on Air Quality in a Medium-Sized Town," Environmental Technology 33 (Nov. 2012): 2467-77, doi:10.1080/09593330.2012.672472.

${ }^{58}$ Rich Baldauf et al., "The Role of Vegetation in Mitigating Air Quality Impacts from Traffic Emissions" (U.S. Environmental Protection Agency, 2011).

${ }^{59}$ David J. Nowak et al., "Modeled PM2.5 Removal by Trees in Ten U.S. Cities and Associated Health Effects," Environmental Pollution 178 (July 2013): 395-402, doi:10.1016/j .envpol.2013.03.050.

${ }^{60}$ Darrel Baumgardner et al., "The Role of a Peri-Urban Forest on Air Quality Improvement in the Mexico City Megalopolis," Environmental Pollution 163 (Apr. 2012): 174-83, doi:10.1016/j.envpol.2011.12.016.

${ }^{61}$ W. J. Bealey et al., "Estimating the Reduction of Urban PM10 Concentrations by Trees within an Environmental Information System for Planners," Journal of Environmental Management 85 (Oct. 2007): 44-58, doi:10.1016/j.jenvman.2006.07.007.

${ }^{62}$ Thomas A. M. Pugh et al., "Effectiveness of Green Infrastructure for Improvement of Air Quality in Urban Street Canyons," Environmental Science and Technology 46 (July 17, 2012): 7692-99, doi:10.1021/es300826w.

${ }^{63}$ D. Bradley Rowe, "Green Roofs as a Means of Pollution Abatement," Environmental Pollution 159, (Sept. 2011): 21002110, doi:10.1016/j.envpol.2010.10.029.

${ }^{64}$ Riccardo Buccolieri et al., "Aerodynamic Effects of Trees on Pollutant Concentration in Street Canyons," Science of the Total Environment 407 (Sept. 15, 2009): 5247-56, doi:10.1016/ j.scitotenv.2009.06.016.

${ }^{65}$ Annett Wania et al., "Analysing the Influence of Different Street Vegetation on Traffic-Induced Particle Dispersion Using Microscale Simulations," Journal of Environmental Management 94 (Feb. 2012): 91-101, doi:10.1016/j.jenvman.2011.06.036.

${ }^{66} \mathrm{~J}$. A. Salmond et al., "The Influence of Vegetation on the Horizontal and Vertical Distribution of Pollutants in a Street Canyon," Science of the Total Environment 443 (Jan. 15, 2013): 287-98, doi:10.1016/j.scitotenv.2012.10.101.

${ }^{67}$ Vos et al., "Improving Local Air Quality in Cities."

${ }^{68}$ Heikki Setälä et al., "Does Urban Vegetation Mitigate Air Pollution in Northern Conditions?," Environmental Pollution 183 (Dec. 2013): 104-12, doi:10.1016/j.envpol.2012.11.010.

${ }^{69}$ Acero et al., "Impact of Local Urban Design and Traffic Restrictions on Air Quality in a Medium-Sized Town." solid or vegetative noise barriers along highways can decrease the amount of air pollution reaching neighborhoods. ${ }^{70,71}$ Factors such as the effects of barrier height and road width require further study. ${ }^{72,73}$ The limited evidence for vegetative barriers suggests that dense vegetation performs similarly to a solid barrier by both blocking and filtering air pollution, with effectiveness depending on wind direction and whether the roadside trees are deciduous or evergreen. ${ }^{74,75,76}$

Bicycle or other active travel lanes can be separated from traffic to reduce TRAP exposure for people breathing heavily during exercise. ${ }^{77,78,79}$ Larger-scale projects like capping highways with decking has been shown to reduce concentrations near one major project. $^{80,81,82}$ However, elevated air pollution levels have been measured in highway tunnels and near vents/exits to

${ }^{70}$ N. Schulte and A. Venkatram, "Effects of Sound Barriers on Dispersion from Roadways,' DRAFT (2013).

${ }^{71}$ Halley L. Brantley et al., "Field Assessment of the Effects of Roadside Vegetation on near-Road Black Carbon and Particulate Matter,' Science of the Total Environment 468-469 (Jan. 15, 2014): 120-29, doi:10.1016/j.scitotenv.2013.08.001.

${ }^{72}$ Schulte and Venkatram, "Effects of Sound Barriers on Dispersion from Roadways."

${ }^{73}$ Brantley et al., "Field Assessment of the Effects of Roadside Vegetation on near-Road Black Carbon and Particulate Matter.',

${ }^{74}$ Baldauf et al., "The Role of Vegetation in Mitigating Air Quality Impacts from Traffic Emissions."

${ }^{75}$ Abdullah N. Al-Dabbous and Prashant Kumar, "The Influence of Roadside Vegetation Barriers on Airborne Nanoparticles and Pedestrians Exposure under Varying Wind Conditions," Atmospheric Environment 90 (June 2014): 11324, doi:10.1016/j.atmosenv.2014.03.040.

${ }^{76}$ Gayle S. W. Hagler et al., "Field Investigation of Roadside Vegetative and Structural Barrier Impact on near-Road Ultrafine Particle Concentrations under a Variety of Wind Conditions," Science of the Total Environment 419 (Mar. 1, 2012): 7-15, doi:10.1016/j.scitotenv.2011.12.002.

${ }^{77}$ Sarah Jarjour et al., "Cyclist Route Choice, Traffic-Related Air Pollution, and Lung Function: A Scripted Exposure Study," Environmental Health 12 (Feb. 7, 2013): 14, doi:10.1186/1476069X-12-14.

${ }^{78}$ Marianne Hatzopoulou et al., "The Impact of Traffic Volume, Composition, and Road Geometry on Personal Air Pollution Exposures among Cyclists in Montreal, Canada," Journal of Exposure Science and Environmental Epidemiology 23 (Feb. 2013): 46-51, doi:10.1038/jes.2012.85.

${ }^{79}$ Luc Int Panis et al., "Exposure to Particulate Matter in Traffic: A Comparison of Cyclists and Car Passengers," Atmospheric Environment 44 (June 2010): 2263-70, doi:10.1016/ j.atmosenv.2010.04.028.

${ }^{80}$ Peter Harnik and Mayor Michael Bloomberg, Urban Green: Innovative Parks for Resurgent Cities, 2nd edition (Washington, DC: Island Press, 2010).

${ }^{81}$ Jonathan Reich, Factors Affecting the Feasibility of Urban Infill Development Over Freeways Another Shade of Green: Implementing Complex Multidisciplinary Work (n.d.).

${ }^{82}$ Robert Cervero, "Transport Infrastructure and Global Competitiveness: Balancing Mobility and Livability," ANNALS of the American Academy of Political and Social Science 626 (Nov. 1, 2009): 210-25, doi:10.1177/0002716209344171. 
decked areas, leading to potentially higher exposures for commuters and people living near vents/exits. ${ }^{83,84,85,86}$

There is increased interest in urban agriculture to improve access to fresh, healthy, affordable food and reduce transportation costs while lowering carbon emissions, ${ }^{87}$ but it has led to questions of how garden location affects exposure. In fact, some vegetables can accumulate pollutants from the air, resulting in a dietary exposure pathway. ${ }^{88,89}$

\section{CHARRETTE METHODS}

In May 2014, the CAFEH team used lessons from their research to organize a charrette that brought together environmental scientists, health researchers, architects, planners, community members, and designers in a creative problem-solving session focused on near-highway projects in Somerville and Boston Chinatown. ${ }^{90}$

\section{Somerville case example}

The City of Somerville, MA, just north of Boston, is highly burdened with TRAP. The city is the most densely populated in New England with 78,000 residents living within $11.6 \mathrm{~km}^{2}$. The city is crossed by I-93, Boston's main North-South highway (about 170,000 vehicles/ day); ${ }^{91}$ Rt. 28, (about 38,000 vehicles/day); ${ }^{92}$ Route 38

\footnotetext{
${ }^{83}$ Christine T. Cowie et al., "Redistribution of Traffic Related Air Pollution Associated with a New Road Tunnel," Environmental Science and Technology 46 (Mar. 6, 2012): 2918-27, doi:10.1021/es202686r.

${ }^{84}$ Christine T. Cowie et al., "Respiratory Health before and after the Opening of a Road Traffic Tunnel: A Planned Evaluation," PLoS ONE 7, (Nov. 29, 2012): e48921, doi:10.1371/ journal.pone.0048921.

${ }^{85}$ Jessica L. Perkins, Luz T. Padró-Martínez, and John L. Durant, "Particle Number Emission Factors for an Urban Highway Tunnel," Atmospheric Environment 74 (Aug. 1, 2013): 326-37, doi:10.1016/j.atmosenv.2013.03.046.

${ }^{86} \mathrm{Yu}-\mathrm{H}$ siang Cheng, Zhen-Shu Liu, and Chih-Chieh Chen, "On-Road Measurements of Ultrafine Particle Concentration Profiles and Their Size Distributions inside the Longest Highway Tunnel in Southeast Asia," Atmospheric Environment 44 (Feb. 2010): 763-72, doi:10.1016/j.atmosenv.2009 .11 .040 .

87 "Urban Agriculture," Urban Agriculture, < https://www.cityof boston.gov/food/urbanag/> (lastaccessedDec.5,2014).

${ }^{88}$ Agnes B. Lobscheid, Randy L. Maddalena, and Thomas E. McKone, "Contribution of Locally Grown Foods in Cumulative Exposure Assessments," Journal of Exposure Analysis and Environmental Epidemiology 14 (Jan. 2004): 60-73, doi:10.1038/ sj.jea.7500306.

${ }^{89}$ Jie Hong et al., "Evidence of Translocation and Physiological Impacts of Foliar Applied $\mathrm{CeO}_{2}$ Nanoparticles on $\mathrm{Cu}-$ cumber (Cucumis Sativus) Plants," Environmental Science and Technology 48, (Apr. 15, 2014): 4376-85, doi:10.1021/ es404931g.

${ }^{90}$ The Community Assessment of Freeway Exposure and Health, Improving Health in Communities Near Highways: Design Solutions from a Charrette (DRAFT) (Boston, MA, n.d.).

91"I-93 North Between Route 28, Charlestown, and the New Hampshire State Line," <ftp://ctps.org/pub/Express_Highway_ Volumes/21_I93_North.pdf> (last accessed Dec. 10, 2014).

92" Grounding McGrath Report," < http://www.massdot.state .ma.us/portals/23/docs/02bchapter2bexistingconditions.pdf > (last accessed Dec. 10, 2014).
}

(about 34,000 vehicles/day); ${ }^{93}$ and other high volume roadways. This results in high UFP levels in residential areas near the roadways. ${ }^{94}$ The Somerville population is economically and ethnically diverse with many low income and immigrant residents living near major roadways. Demand for housing and commercial space combined with little developable land has resulted in pressure to develop near highways.

A vacant site in the city was selected to be a test case in our charrette to consider pollutant exposure mitigation strategies. The site is located $<200$ meters from both Interstate 93 (I-93) and McGrath Highway (Rt. 28), and is next to a Stop and Shop supermarket. Surrounding the site is a small abandoned park and a neighborhood of two and three family homes. The nearby area includes several commercial buildings and Foss Park, the largest park in Somerville (Figure 1). The site is zoned for commercial use, but a residential developer aims to amend the zoning to allow residential development. The vacant parcel, located near so many TRAP sources, is similar to much of the remaining developable land in the city.

Concepts that emerged in the charrette ranged from design elements for the proposed housing to neighborhoodwide plans. Multiple types of barriers were considered. There are currently no sound walls along I-93 or McGrath near the site. Rather than traditional walls, charrette participants opted for more functional barriers such as minimally occupied structures including parking garages and commercial buildings (with high efficiency filtration) situated between the highway and the proposed new housing. Participants also considered vegetation buffers to be planted in the abandoned playground next to I-93. The goal was to reserve areas farther from the highway for more sensitive, residential uses, while also blocking flow of pollutants into residential areas (Figure 2). ${ }^{95}$

Concepts designed to reduce exposure at the nearby and heavily utilized Foss Park included creating earthen berms around the edges and a shell performance stage as functional barriers. In addition, participants recommended siting more active park elements, such as sports fields, farthest from the highways. While the focus of the charrette was on new development or redevelopment, addressing the pollution exposure of current residents was also considered. One recommendation was to provide

\footnotetext{
93،Road Safety Audit: Mystic Avenue (Route 38)/Temple Street/Temple Road City of Somerville," < http://www .massdot.state.ma.us/Portals/8/docs/traffic/SafetyAudit/District4/ Somerville_MysticAve_TempleSt_061614.pdf > (last accessed Dec. 10, 2014).

${ }^{94}$ Padró-Martínez et al., "Mobile Monitoring of Particle Number Concentration and Other Traffic-Related Air Pollutants in a near-Highway Neighborhood over the Course of a Year," Dec. 2012.

${ }^{95}$ Doug Brugge et al., Improving Health in Communities Near Highways: Design Ideas from a Charrette. Community Assessment of Freeway Exposure and Health (Nov. 2014), <https:// sites.tufts.edu/cafeh/files/2011/10/CAFEH-Report-Final-2-26-15hi-res.pdf $>$.
} 
FIG. 1. The Cross Street East site in Somerville. The site is located near both I-93 and Route 28. Credit: D. Brugge, J. Durant, A. Patton, J. Newman, and W. Zamore. Improving Health in Communities Near Highways: Design Ideas from a Charrette. Community Assessment of Freeway Exposure and Health. Nov, 2014. Available at: <https://sites.tufts.edu/ cafeh/files/2011/10/CAFEHReport-Final-2-26-15-hi-res .pdf $>$.

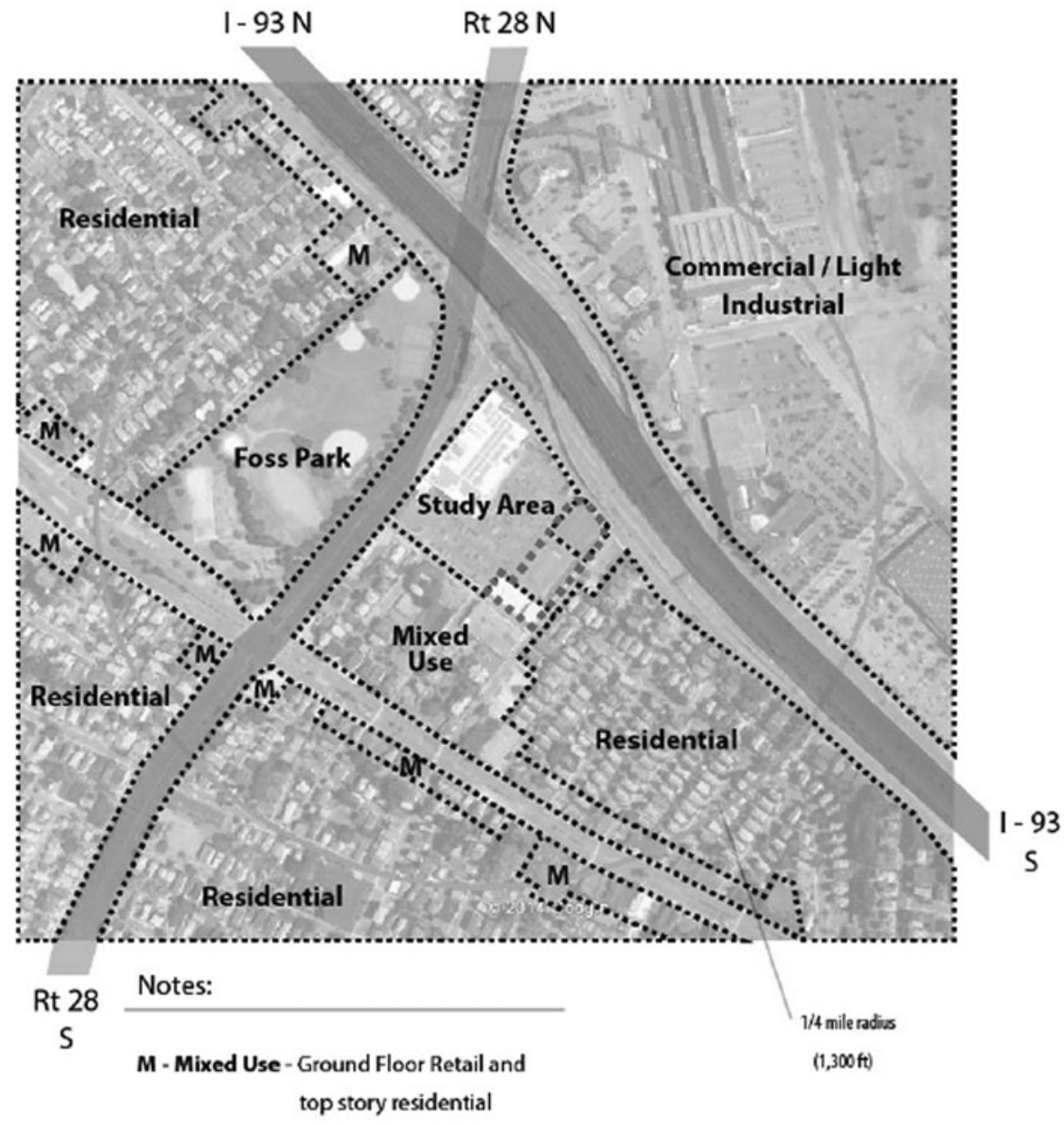

Above-Ground Highway

Ground-level Highway

" = " Site Location

residents near the highway with weatherization and filtering options, potentially through a city loan program.

Following the charrette, our work in Somerville with respect to this site has continued. We presented some of the charrette ideas to developers and are exploring ways to enhance the air filtration systems they propose to use in the housing, should it be approved for construction.

\section{Boston Chinatown case example}

Boston Chinatown is an historic neighborhood near the heart of downtown that lies at the junction of the Massachusetts Turnpike (I-90) and the I-93 expressway; most of the community's housing lies within 400 meters of the highway. Its surface streets are major access points to and from the highways. Chinatown is also Boston's densest neighborhood, with only $5.1 \%$ tree canopy coverage, compared to $28 \%$ for the city overall.
On the east side of Boston Chinatown lies a 20-acre tangle of highway ramps and empty land, owned by the Massachusetts Department of Transportation and designated as an important area for economic development. It was labelled the "Chinatown Gateway Special Study Area" in the 1990s. In 2013, as luxury downtown development made available parcels scarcer and even more valuable, Boston's outgoing mayor proposed to build a new \$261 million two-school facility for the Josiah Quincy Upper School and the Boston Arts Academy on one of the Chinatown Gateway sites known as Parcel 25. The project would place more than one thousand public school students into a school that straddles an I-93 onramp and tunnel exit (Figure 3). Despite vocal concerns about the children's safety and health, the community has been largely supportive of the project, with no other suitable development location available in Chinatown. 


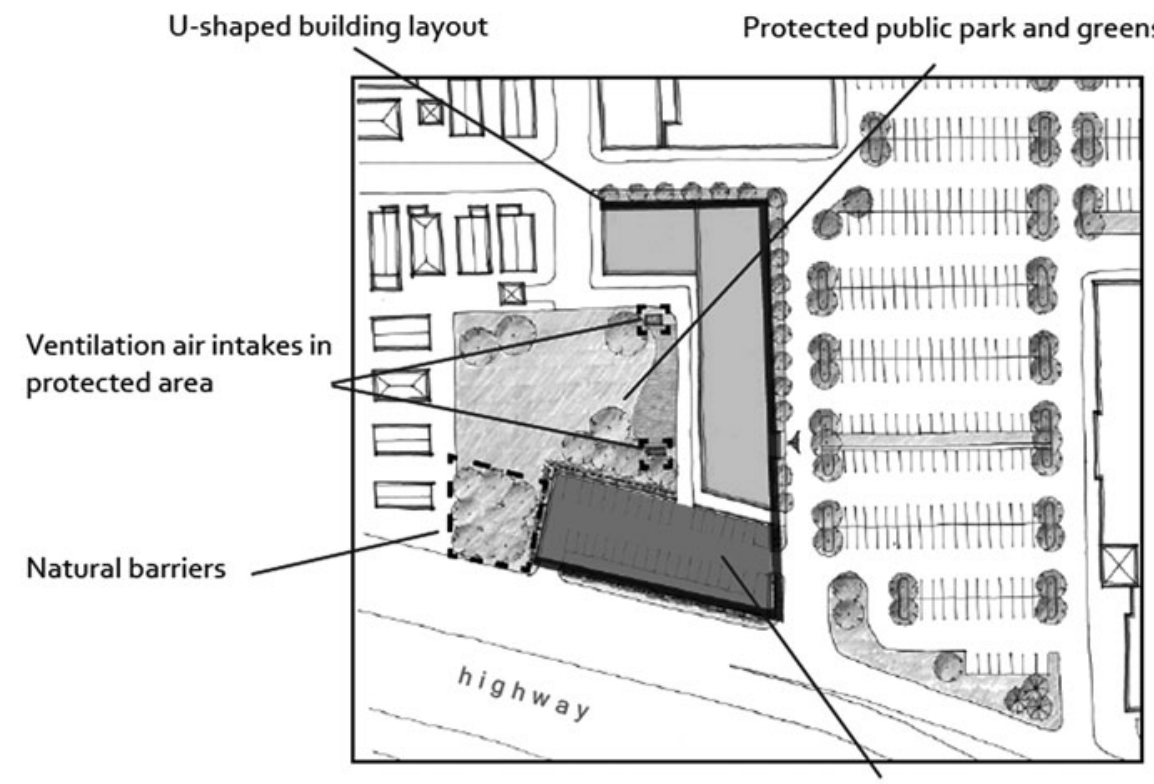

FIG. 2. A design to reduce exposure to traffic-related air pollutants (TRAP) at the site in Somerville. Credit: D. Brugge, J. Durant, A. Patton, J. Newman, and $\mathrm{W}$. Zamore. Improving Health in Communities Near Highways: Design Ideas from a Charrette. Community Assessment of Freeway Exposure and Health. Nov, 2014. Available at: < https://sites.tufts .edu/cafeh/files/2011/ 10/CAFEH-Report-Final2-26-15-hi-res.pdf > .

Multi-story parking garage as barrier toward highway (with exterior green wall)

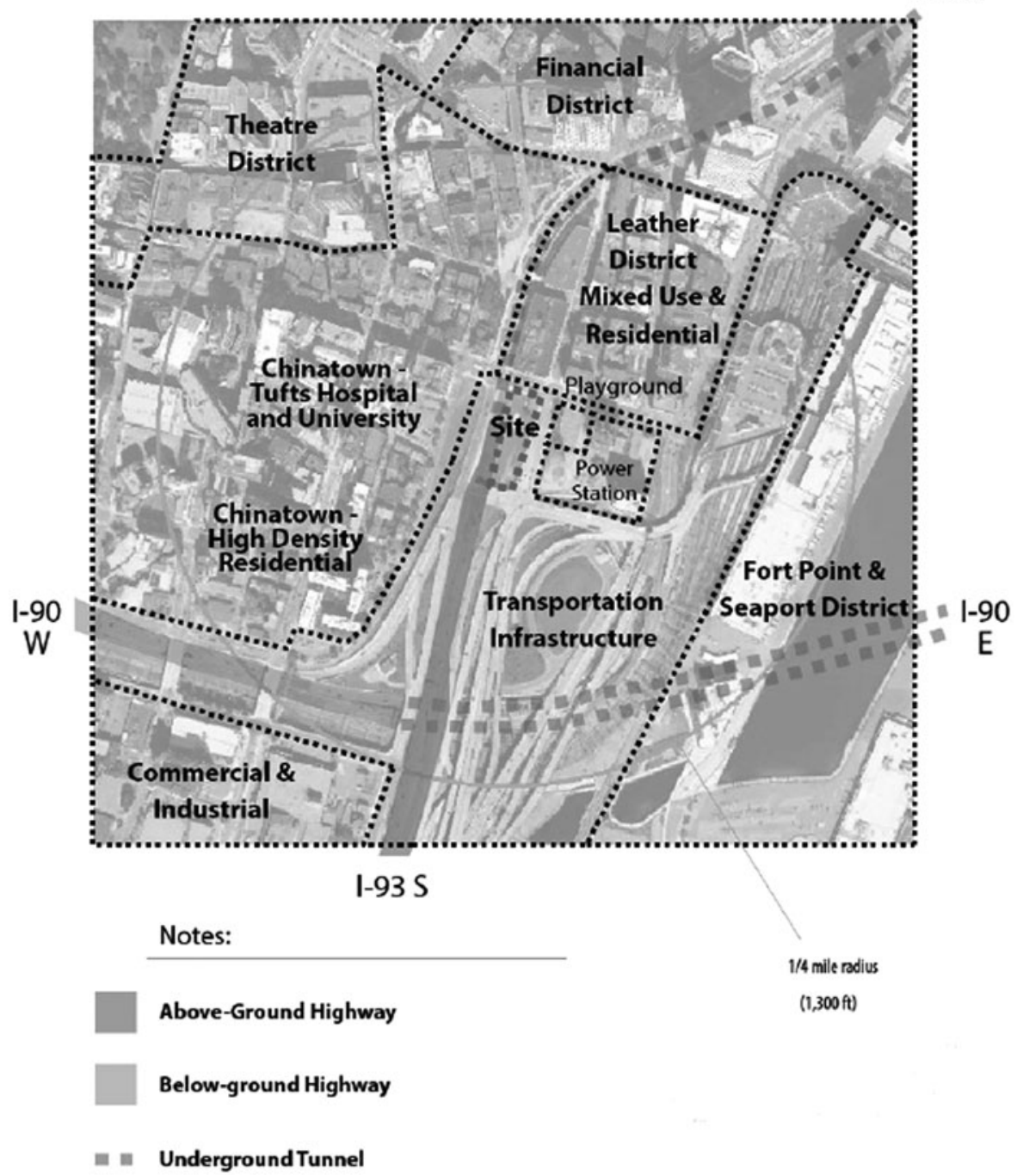

FIG. 3. The Parcel 25 site in Chinatown. The site is located directly above I-93 at a tunnel exit. Credit: D. Brugge, J. Durant, A. Patton, J. Newman, and $\mathrm{W}$. Zamore. Improving Health in Communities Near Highways: Design Ideas from a Charrette. Community Assessment of Freeway Exposure and Health. Nov, 2014. Available at: <https://sites .tufts.edu/cafeh/files/2011/10/ CAFEH-Report-Final-2-2615-hi-res.pdf $>$. 


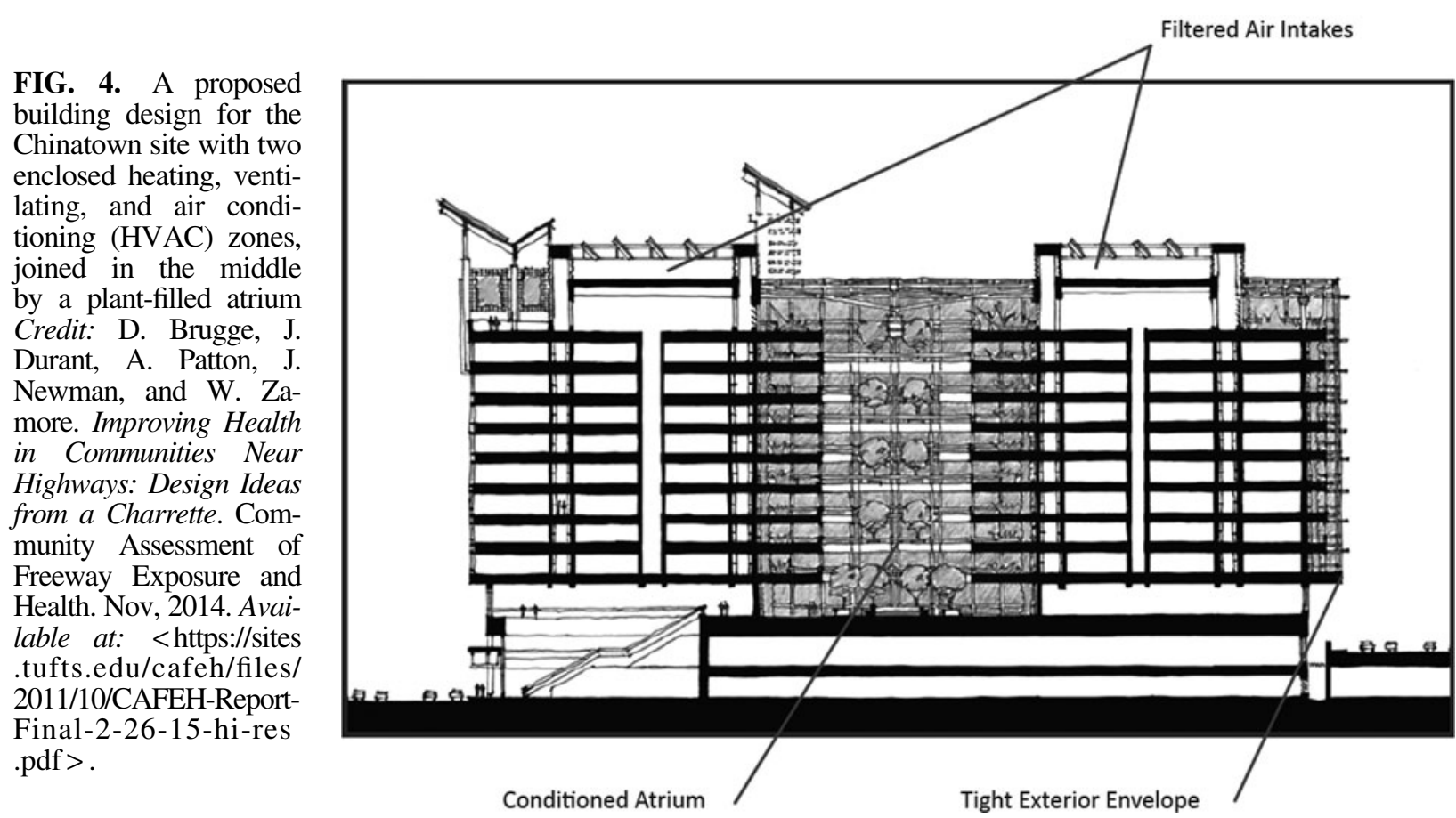

The charrette produced a host of mitigation ideas. One of the central concepts was to incorporate high-quality air filtration into the heating, ventilating, and air conditioning (HVAC) system of the school, paying attention to the siting of air intake units as far from the highways as possible. Other ideas included physical or vegetative barriers between the highway and the building and a large atrium with filtered air and plantings within the building interior (Figure 4). A broader recommendation was to call upon the state Department of Transportation to deck over the highways and provide large-scale air filtering of tunnel exhaust. Chinatown community members expressed that mitigation was both an environmental justice issue and a form of reparations to a community that was destroyed to make way for the highways over fifty years ago.

Post-charrette, the architectural team for the school project altered its building design to relocate air intake units on the rooftop as far from traffic pollution sources as possible, combined with $100 \%$ replacement air, and incorporated high-MERV air filters into its HVAC system design. Since then, plans for the school have been put on hold by Boston's new mayor, but one of the project's architects has become a vocal advocate of this type of healthy building design and will hopefully bring this knowledge into future near-highway schools.

\section{Municipal strategies}

Municipalities have a range of tools at their disposal for enhancing the health and well-being of residents living near highways. While fine particulate matter is regulated at both the federal and state levels, the lack of federal and state standards on UFP has hampered municipal efforts to mitigate the negative health effects of UFP exposure. Since TRAP concentrations are highly variable and challenging to predict, many municipal responses have included air quality testing requirements. Monitoring is also crucial to further research on the health impacts from UFP. ${ }^{96}$

The most effective regulatory model, either through zoning or a standalone law, is to restrict what can be built within a defined buffer zone around high pollution roadways. For example, regulation might include restrictions on the location of residences, schools, and active parkland. Non-restricted building types could be permitted within a buffer zone, subject to indoor air quality standards. California restricts siting schools within 500 feet of urban highways (more than 100,000 vehicles per day [vpd]) and rural highways (more than 50,000 vpd) unless prescribed conditions are met. ${ }^{97}$ This restriction, while not codified by federal standards, sets the stage for municipalities to define high pollution exposure zones and land use guidelines for near highway locations. However, in many urban settings this is not sufficient as urban building densities, including schools and housing, around highways and other high-traffic roadways are already established.

Communities may be able to require protective air filtration for residential or school buildings within a

\footnotetext{
${ }^{96}$ Environmental Protection Agency. Near Roadway Air Pollution and Health (Aug. 2014), <http://www.epa.gov/otaq/ nearroadway.htm >.

${ }^{97}$ California Legislative Information. Senate Bill No. 352, Chapter 668. "An act to amend Section 17213 of the Education Code, and to amend Section 21151.8 of the Public Resources Code, relating to public schools."
} 
buffer zone of highly traveled roadways through ordinances or conditions put on new developments. In California, the community of Jurupa Valley focused on very specific pollution conditions and forced a legal settlement with companies and municipalities that mandates and pays for filtration in residences and schools within a specified buffer zone. ${ }^{98}$ New construction of multi-family affordable housing near highways may offer an opportunity for other municipalities to take similar measures.

\section{CONCLUSION}

The growth of interest in "green buildings" and "healthy homes" has mostly focused on addressing indoor sources of air pollution. We show here that there is an equally important need to consider and prevent exposure to ambient pollutants that infiltrate into homes and schools. While there is a need for more research on the tactics described in this article, we feel that it is possible, with the evidence available now, to better protect people from TRAP emanating from high traffic roadways.

\section{ACKNOWLEDGMENTS}

We thank the Kresge Foundation for their support of the work reported here. The original research from CAFEH was funded by a National Institute of Environmental Health Sciences (NIEHS) grant (ES015462), the Jonathan M. Tisch College of Citizenship and Public Service (through the Tufts Community Research Center), U.S. Environmental Protection Agency (EPA) (FP-917203, FP-917349), and a P.E.O. Scholar award. Dr. Patton was partially supported by an
NIEHS training grant in exposure science to Rutgers University (T32 ES198543). Participants in the charrette, besides the authors, were: David Arond, Brad Bellows, Jeremy Bowman, Richard Chang, Damon Chaplin, Lawrence Cheng, Meera Deean, Martine Dion, Shauna Gillies-Smith, Chin Lin, George Proakis, Denise Provost, Matt Simon, Josh Safdie, David Spillane, Dee Spiro, Noèmie Sportiche, Anne Tate, Terry Yin, Felix Zemel, Michael Ginieres, John Gravelin, Sherry Hou, Peter James, Sae Kim, Jon Levy, Dana Lewinter, Angie Liou, and Yi Qi Lu.

\section{AUTHOR DISCLOSURE STATEMENT}

Dr. Brugge has received funding from: International Physicians for the Prevention of Nuclear War to participate in a 2013 Uranium Mining Conference in Tanzania, Better World Fund to participate in a 2014 Health Effects of Fine Particles from Vehicle Emissions Workshop, and Uranium-Network.org to participate in the 2014 Freiberg Uranium Conference. All other authors have no conflicts of interest or financial ties to disclose.

\author{
Address correspondence to: \\ Doug Brugge \\ Tufts University School of Medicine \\ 136 Harrison Avenue \\ Boston, MA 02111
}

E-mail: dbrugge@aol.com

\footnotetext{
${ }^{98}$ State of California Department of Justice, Office of the Attorney General. "Attorney General Kamala D. Harris Announces Settlement to Protect Public Health in Jurupa Valley" (Feb. 2013).
} 